\title{
INDIRECT DECOMPRESSION BY LATERAL FUSION: ANALYSIS OF SAGITAL ALIGNMENT
}

\author{
DESCOMPRESSÃO INDIRETA POR FUSÃO LATERAL: ANÁLISE DO ALINHAMENTO SAGITAL
} DESCOMPRESIÓN INDIRECTA POR FUSIÓN LATERAL: ANÁLISIS DE LA ALINEACIÓN SAGITAL

Thyago Guirelle Silva, ${ }^{1}$ Rodrigo Augusto do Amaral, ${ }^{1}$ Raphael Rezende Pratali, ${ }^{1}$ Luiz Pimenta, ${ }^{2}$

1. Instituto de Patologia da Coluna - IPC, São Paulo, SP, Brazil.

2. University of California San Diego - UCSD, Department of Neurosur-gery, San Diego, USA.

\begin{abstract}
Objective: To verify the effectiveness of indirect decompression after lateral access fusion in patients with high pelvic incidence. Methods: A retrospective, non-comparative, non-randomized analysis of 22 patients with high pelvic incidence who underwent lateral access fusion, 11 of whom were male and 11 female, with a mean age of 63 years (52-74), was conducted. Magnetic resonance exams were performed within one year after surgery. The cross-sectional area of the thecal sac, anterior and posterior disc heights, and bilateral foramen heights, measured pre- and postoperatively in axial and sagittal magnetic resonance images, were analyzed. The sagittal alignment parameters were measured using simple radiographs. The clinical results were evaluated using the ODI and VAS (back and lower limbs) questionnaires. Results: In all cases, the technique was performed successfully without neural complications. The mean cross-sectional area increased from $126.5 \mathrm{~mm}$ preoperatively to $174.3 \mathrm{~mm}$ postoperatively. The mean anterior disc height increased from $9.4 \mathrm{~mm}$ preoperatively to $12.8 \mathrm{~mm}$ postoperatively, while the posterior disc height increased from $6.3 \mathrm{~mm}$ preoperatively to $8.1 \mathrm{~mm}$ postoperatively. The mean height of the right foramen increased from $157.3 \mathrm{~mm}$ in the preoperative period to $171.2 \mathrm{~mm}$ in the postoperative period and that of the left foramen increased from $139.3 \mathrm{~mm}$ in the preoperative to $158.9 \mathrm{~mm}$ in the postoperative. Conclusions: This technique is capable of correcting misalignment in spinal deformity, achieving fusion and promoting the decompression of neural elements. Level of evidence III; Retrospective study.
\end{abstract}

Keywords: Arthrodesis; Spinal Stenosis; Decompression.

\section{RESUMO}

Objetivo: Verificar a eficácia da descompressão indireta depois de fusão por acesso lateral em pacientes com alta incidência pélvica. Métodos: Análise retrospectiva, não comparativa, não randomizada de 22 pacientes com alta incidência pélvica submetidos à fusão por acesso lateral; 11 do sexo masculino e 11 do sexo feminino, com média de idade de 63 anos (52 a 74). Os exames de ressonância magnética foram realizados até um ano depois da cirurgia. Foram analisadas: área da seção transversal do saco tecal, altura discal anterior e posterior, altura dos forames bilaterais, medidas no pré e pós-operatório em imagens de ressonância magnética axial e sagital. Os parâmetros do alinhamento sagital foram medidos a partir de radiografia simples. Os resultados clínicos foram avaliados com os questionários ODI e EVA (costas e membros inferiores). Resultados: Em todos os casos, a técnica foi realizada com sucesso, sem complicações neurais. A área da secção transversal média aumentou de 126,5 mm no pré-operatório para 174,3 mm no pós-operatório. A média da altura anterior do disco aumentou de 9,4 mm no pré-operatório para 12,8 mm no pós-operatório, enquanto a altura posterior do disco aumentou de 6,3 mm no pré-operatório para 8,1 mm no pós-operatório. A média da altura do forame direito aumentou de 157,3 $\mathrm{mm}$ no pré-operatório para 171,2 mm no pós-operatório e a do forame esquerdo aumentou de 139,3 mm no pré-operatório para 158,9 mm no pós-operatório. Conclusões: Essa técnica é capaz de corrigir o desalinhamento na deformidade da coluna vertebral, alcançando a fusão e promovendo a descompressão dos elementos neurais. Nível de evidência III; Estudo Retrospectivo.

Descritores: Artrodese; Estenose Espinhal; Descompressão.

\section{RESUMEN}

Objetivo: Verificar la eficacia de la descompresión indirecta después de fusión por acceso lateral en pacientes con alta incidencia pélvica. Métodos: Análisis retrospectivo, no comparativo, no aleatorizado de 22 pacientes con alta incidencia pélvica sometidos a fusión por acceso lateral; 11 del sexo masculino y 11 del sexo femenino, con promedio de edad de 63 años (52 a 74). Los exámenes de resonancia magnética fueron realizados hasta un año después de la cirugía. Fueron analizadas: área de la sección transversal del saco dural, altura discal anterior y posterior, altura de los forámenes bilaterales, medidas en el pre y posoperatorio en imágenes de resonancia magnética axial y sagital. Los parámetros de la alineación sagital fueron medidos a partir de una radiografía simple. Los resultados clínicos fueron evaluados con los cuestionarios ODI y EVA (espalda y miembros inferiores). Resultados: En todos los casos, la técnica fue realizada con éxito, sin complicaciones neurales. El área de la sección transversal promedio aumentó de 126,5 mm en el preoperatorio para 174,3 mm en el postoperatorio. El promedio de altura anterior del disco aumentó de 9,4 $\mathrm{mm}$ en el preoperatorio para 12,8 $\mathrm{mm}$ en el postoperatorio, mientras que la altura posterior del disco 
aumentó de 6,3 $\mathrm{mm}$ en el preoperatorio para 8,1 $\mathrm{mm}$ en el postoperatorio. El promedio de altura del foramen derecho aumentó de 157,3 mm en el preoperatorio para 171,2 $\mathrm{mm}$ en el postoperatorio y la del foramen izquierdo aumentó de 139,3 $\mathrm{mm}$ en el preoperatorio para 158,9 mm en el postoperatorio. Conclusiones: Esta técnica es capaz de corregir la desalineación en la deformidad de la columna vertebral, alcanzando la fusión y promoviendo la descompresión de los elementos neurales. Nivel de evidencia III; Estudio retrospectivo.

Descriptores: Artrodesis; Estenosis Espinal; Descompresión.

\section{INTRODUCTION}

Lumbar stenosis is a change that occurs frequently in elderly patients and also a reason for surgical indication at advanced ages. ${ }^{1}$ With the continuing increase in life expectancy, an increased incidence of stenosis is expected. While the exact incidence is unknown, it is estimated that lumbar stenosis affects between 3 and 12 patients out of every 100,000 inhabitants older than 65 years of age annually. ${ }^{2}$

Spinal stenosis results in a narrowing of the canal, resulting from degenerative changes in various elements (facet hypertrophy, bulging discs, and redundancy of the yellow ligament) that cause the neural structures to be confined by the bones of the spine and adjacent soft parts. ${ }^{2}$ In general, the onset of symptoms is slow and gradual, however, they can be exacerbated by trauma and intense activity.

Degenerative stenosis can involve the central canal, the lateral recess, the foramina, or a combination of these, the latter being the most common cause of acquired stenosis, especially affecting adults and the elderly. ${ }^{1,5}$ Canal stenosis occurs more frequently at level L4L5, followed by L5S1 and L3L4. ${ }^{4}$ However, it is necessary to be aware that stenosis may be associated with secondary causes, such as disc herniation, spondylolisthesis, and Paget's disease, which exacerbate the narrowing. ${ }^{1,4}$

Lateral lumbar interbody fusion (LLIF) is a minimally invasive surgery (MIS) technique dedicated to the treatment of degenerative spinal problems, including adult spinal deformity. Pimenta et al. described the LLIF technique and demonstrated its potential advantages in comparison to other surgical techniques, showing its capacity for indirect decompression of the neural elements, restoration of disc height (DH), less tissue trauma, reduced postoperative pain, a shorter hospitalization, and a more rapid return to work. ${ }^{6}$

The ability of the LLIF technique to indirectly decompress the neural structures by retention of the anterior and posterior longitudinal ligaments was demonstrated in several subsequent publications. ${ }^{7,8}$

The objective of this study was to retrospectively evaluate the clinical and radiological effects of distraction promoted by the LLIF technique, in combination or not with posterior pedicular supplementation, for the treatment of central spinal stenosis in adults with high pelvic incidence, as well as the surgical time and blood loss of the procedure.

\section{METHODS}

\section{Patients}

This was a retrospective clinical study of patients with canal stenosis who underwent lateral lumbar interbody fusion (LLIF). The study was approved by the Institutional Review Board as number 24010619.0.0000.5455.

Patients who filled out the Informed Consent Form (ICF), had received LLIF of one or more levels to treat stenosis, had magnetic resonance images from the preoperative period and from some point in the postoperative period up to one year following surgery, and who had responded to at least one clinical questionnaire (Oswestry Disability Index or VAS) preoperatively, postoperatively, and at the one-year follow-up were included.

Patients whose images did not permit visualization of the target project structures and whose MR did not have a scale or DICOM to permit measuring of any of the target structures were excluded. The patient inclusion and exclusion workflow is shown below in Figure 1.
All patients included in the study underwent an MR examination prior to the surgical procedure and at the last postoperative follow-up visit for analysis of the parameters of interest. The cross-sectional area of the thecal sac (CSA), anterior disc height $(A D H)$, posterior disc height $(\mathrm{PDH})$, right foramen height $(\mathrm{RFH})$, and left foramen height (LFH) were measured preoperatively and postoperatively from T2-weighted MR images in axial and sagittal cuts (Figures 1 and 2). Segmental lordosis (SL) between the upper plateau of the cranial vertebra and the lower plateau of the caudal vertebra of the operated level was also considered and pelvic incidence, pelvic version, sacral slope, and lumbar lordosis (measured from L1-S1) were measured from lateral simple radiographs. All the measurements of the considered parameters were taken by Horos (Nimble Co LLC, MD) and Surgimap Spine (Nemaris Inc., New York, USA) programs.

\section{Statistical analysis}

The data were statistically analyzed using the GraphPad Prism 8 program (GraphPad, La Jolla, CA). The difference between the

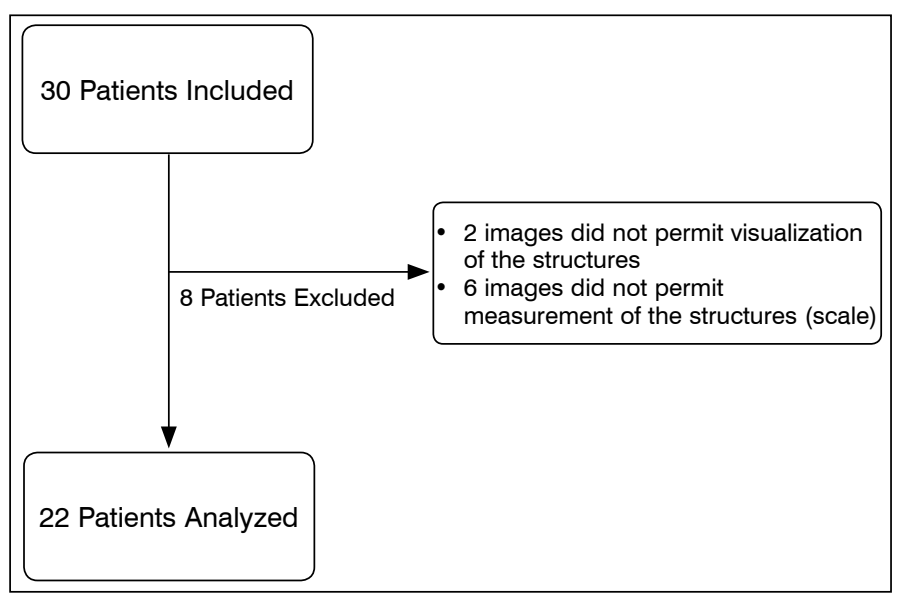

Figure 1. Patient inclusion and exclusion workflow. Imaging examinations and parameters considered.

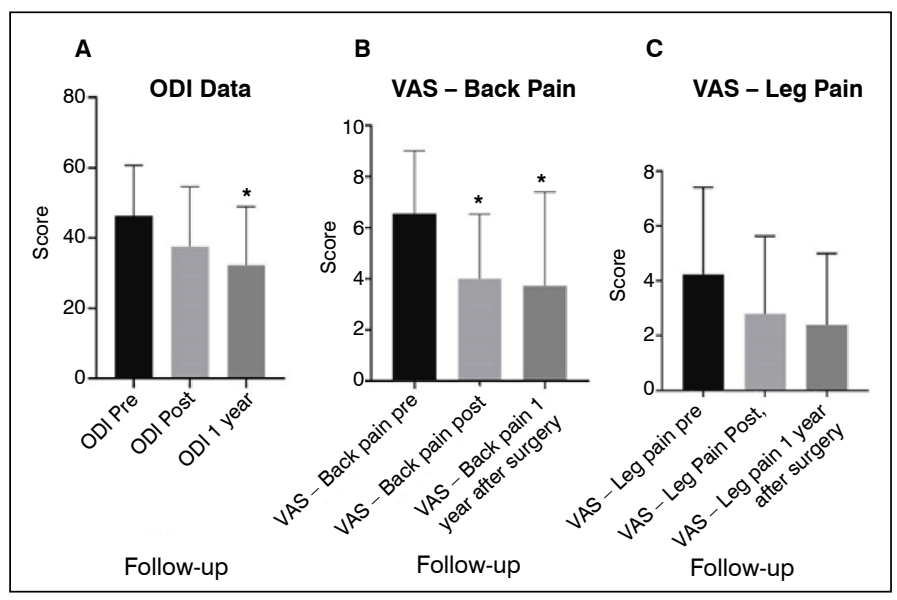

Figure 2. Clinical results accessed from the clinical questionnaires. (A) Physical limitation results ob-tained by $\mathrm{ODI}{ }^{*} \mathrm{p}=0.009$ (one-way non-parametric ANOVA); (B) Lumbar pain results from the VAS* $p<0.003$ (one-way mixed ANOVA); (C) Leg pain results from the VAS (one-way repeated ANOVA). 
group measurements was calculated by the one-way repeated ANOVA test or the one-way mixed ANOVA test (in the case of missing data) for parametric tests and the non-parametric ANOVA test for non-parametric values. The correlation between different variables was performed using Pearson's correlation test (variables with normal distribution) and Spearman's correlation coefficient (variables with non-parametric distribution). The Shapiro-Wilk and D'Agostino-Pearson (omnibus) tests were used to analyze normality, and to be considered normal, the sample had to pass both normality tests. A p-value less than 0.05 was adopted to indicate statistical significance.

\section{RESULTS}

Twenty-two patients with a mean age of 63 years, $50 \%$ of whom were female, were included in the study. The total number of levels included was 28 with the number of levels operated per patient ranging from 1 to 3 , while the most often approached level was L4L5 (64\% of cases). (Table 1 )

The procedures were performed without the occurrence of important intraoperative complications, with a mean duration of 141.5 minutes and with blood loss less than $117 \mathrm{cc}$. As regards the sagittal parameters, the population had a mean pelvic incidence of $59.6^{\circ}$ and mean lumbar lordosis of $48.9^{\circ}$. (Table 2)

The clinical results accessed from the questionnaires showed improved symptoms. There was a significant improvement both in physical limitations, represented by the ODI, and back pain, represented by the VAS $(p=0.0083$ and $p=0.013)$, respectively. However, there was no significant difference in the VAS for leg pain $(p=0.1)$. (Figure 2$)$

The mean CSA increased from a preoperative value of $126.5 \mathrm{~mm}$ to $174.3 \mathrm{~mm}$ in the postoperative period, a mean gain of $77.55 \%$ $(p<0.001$, t test). (Figure 3A) The mean ADH increased from $9.4 \mathrm{~mm}$ in the preoperative period to $12.8 \mathrm{~mm}$ in the postoperative period, for a mean gain of $56.98 \%(p=0.003$, t test), while the mean PDH increased from $6.3 \mathrm{~mm}$ in the preoperative period to $8.1 \mathrm{~mm}$ in the postoperative period, for a mean gain of $77 \%(p=0.06$, non-parametric Wilcoxon test). (Figure 3B) The mean RFH increased from $157.3 \mathrm{~mm}$ in the preoperative period to $171.2 \mathrm{~mm}$ in the postoperative period $(p=0.09$, non-parametric Wilcoxon test), corresponding to a mean gain of $18 \%$, while the mean LFH increased from $139.3 \mathrm{~mm}$ in the preoperative period to $158.9 \mathrm{~mm}$ in the postoperative period, with a mean gain of $38 \%(p=0.02$, t test). (Figure 3C) Mean preoperative segmental lordosis went from $4.6^{\circ}$ to $6.7^{\circ}$, corresponding to a gain of $2.1^{\circ}(p=0.04$, non-parametric Wilcoxon test). (Figure 3D)

Table 1. Patient demographic data.

\begin{tabular}{c|c}
\hline Variable & Values \\
\hline Sex (male/female) & $11 / 11$ \\
\hline \multirow{3}{*}{ Side of approach } & Right $-12(42 \%)$ \\
\cline { 2 - 2 } & Left $-7(26 \%)$ \\
\cline { 2 - 2 } & Not informed $-9(32 \%)$ \\
\hline \multirow{3}{*}{ Levels operated } & L2L3 - $(10 \%)$ \\
\cline { 2 - 2 } & L3L4 - $7(26 \%)$ \\
\hline Age (mean/士SD) & L4L5 - 18 (64\%) \\
\hline \multirow{3}{*}{ Total levels operated } & $63( \pm 11)$ \\
\cline { 2 - 2 } & $1-18(81 \%)$ \\
\cline { 2 - 2 } & $2-2(9 \%)$ \\
\hline
\end{tabular}

Table 2. Results of the sagittal parameters evaluated.

\begin{tabular}{c|c}
\hline Variable & Values \\
\hline Pelvic incidence $^{\circ}(\mathrm{SD})[\mathrm{Cl} 95 \%]$ & $59.6( \pm 5.4)[57.4-61.8]$ \\
\hline Lumbar lordosis $^{\circ}$ (SD) [Cl 95\%] & $48.9( \pm 11.7)[42.4-55.4]$ \\
\hline Sacral slope $^{\circ}$ (SD) [Cl 95\%] & $30.2( \pm 10.1)[24.5-35.8]$ \\
\hline Pelvic version $^{\circ}$ (SD) $[\mathrm{Cl} 95 \%]$ & $25.4( \pm 3.2)[23.6-27.2]$ \\
\hline Segmental lordosis $^{\circ}$ (SD) $[\mathrm{Cl} 95 \%]$ & $4.6( \pm 3.4)[3.2-5.9]$ \\
\hline
\end{tabular}

Figures $4 \mathrm{~A}$ and $4 \mathrm{~B}$ show the pre- and postoperative radiographic results.

The linear correlation between the variation in the size of the canal and the following variables was also calculated: gain in segmental lordosis, gain in left and right foramina, gain in anterior and posterior disc heights. (Table 3) It was verified that the canal opening is directly correlated to the pelvic incidence of the patient and the gain in the height of the left foramen is inversely correlated to the opening of the central canal, whereas the other parameters did not demonstrate any correlation with canal decompression.

\section{DISCUSSION}

Studies of LLIF in patients with high pelvic incidence and its efficiency in achieving indirect neural decompression by means of disc height restoration are limited. All 22 patients with high pelvic incidence were treated successfully with LLIF. The effect of indirect neural decompression was analyzed by comparing the pre- and postoperative lumbosacral spine MR and radiographic results.

Unlike direct anterior or posterior surgical approaches, lateral access keeps the anterior and posterior longitudinal ligaments intact, allowing placement of an implant with a large area of contact with the vertebral plateau, resulting in a biomechanically very stable construction. ${ }^{9-12}$ In addition, it reduces the risk of direct neural injury, epidural hematoma formation, iatrogenic durotomy, peridural bleeding, and post-laminectomy instability. ${ }^{11,12}$ The

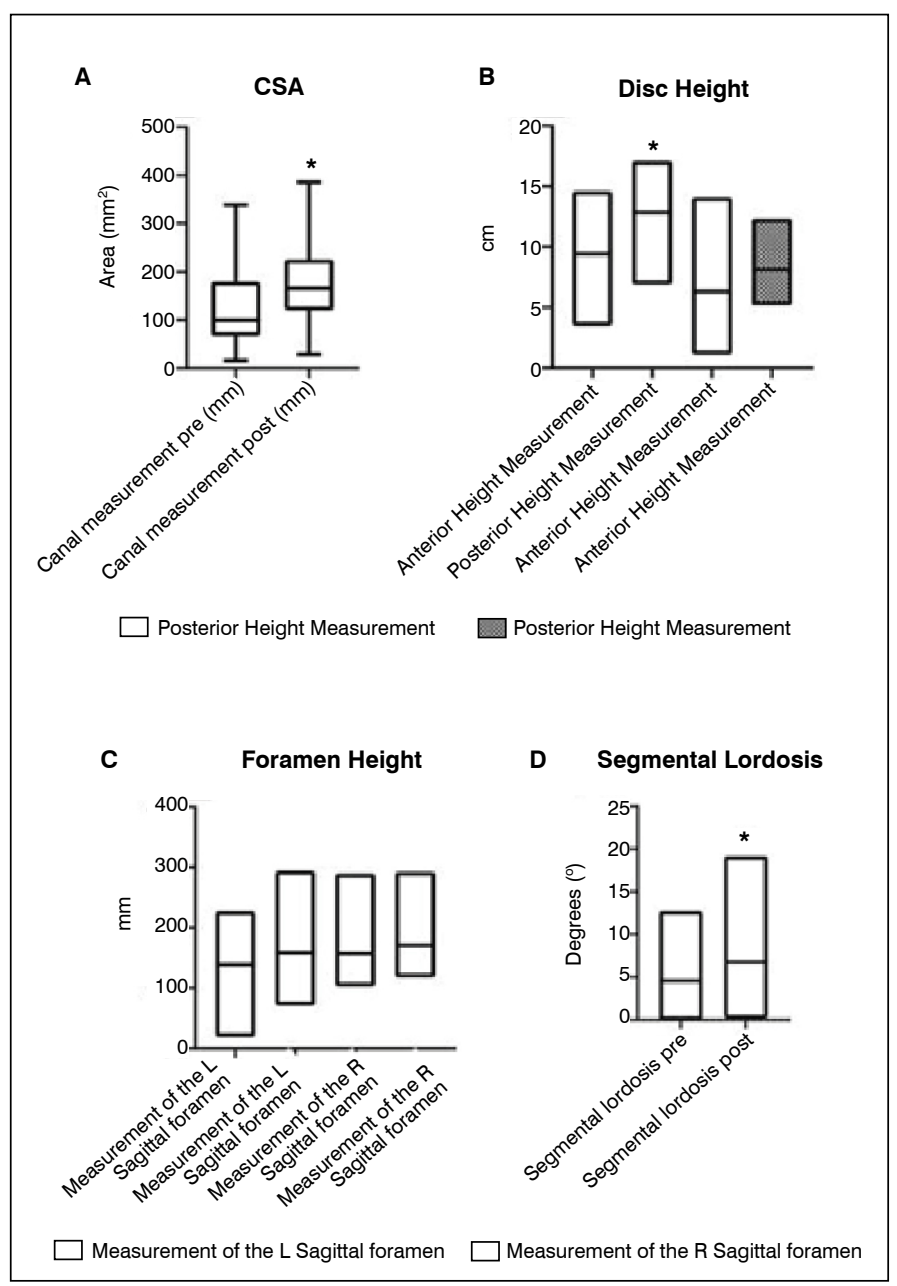

Figure 3. (A) Difference between the area of the central canal. (B) - Difference between the anterior and posterior heights, $(C)$ - Difference between the right and left foraminal heights, (D) - Difference between the segmental lordosis, * indicates $p<0.05$. 


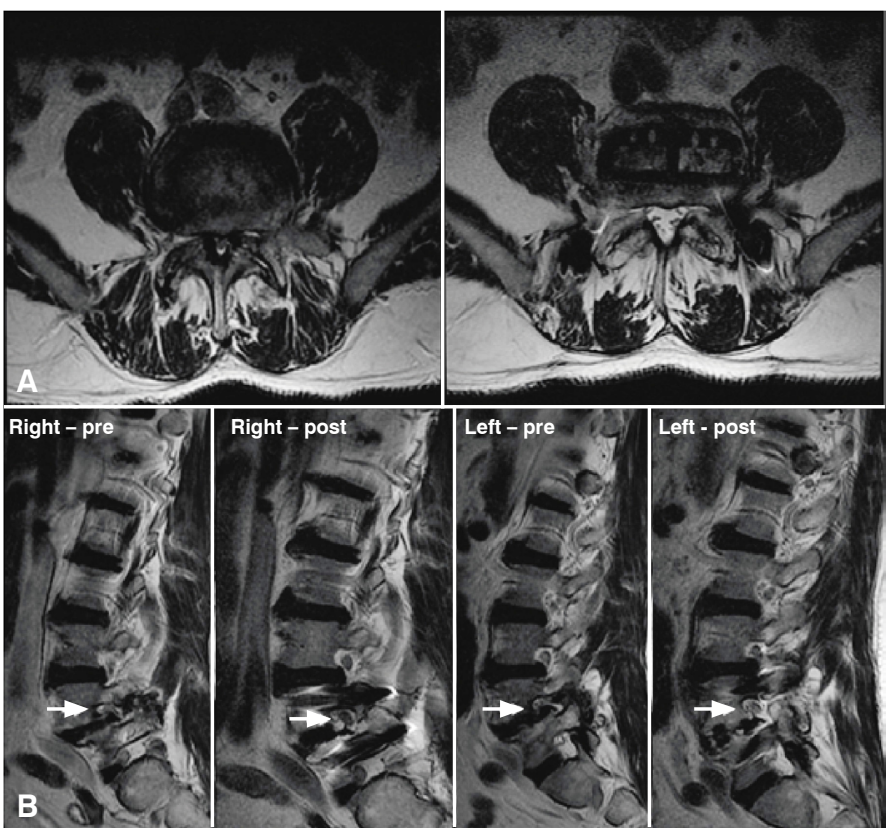

Figure 4. A. Pre- and postoperative T2-weighted axial magnetic resonance images. B. Pre- and postoperative T2-weighted sagittal magnetic resonance images of the right and left foramina.

Table 3. Results of the linear regression analysis.

\begin{tabular}{c|c|c|c|c|c}
\hline \multicolumn{2}{c|}{ Pearson's correlation test } & \multicolumn{3}{c}{ Spearman's correlation test } \\
\hline Variable (n) & $\mathbf{R}^{\mathbf{2}}$ & $\mathbf{p}$ & Variable (n) & $\mathbf{r}$ & $\mathbf{p}$ \\
\hline Pelvic incidence (28) & 0.20 & 0.015 & $\begin{array}{c}\text { Gain in lumbar } \\
\text { lordosis (28) }\end{array}$ & 0.14 & 0.46 \\
\hline $\begin{array}{c}\text { Gain in segmental } \\
\text { lordosis (28) }\end{array}$ & 0.01 & 0.55 & Pelvic version (28) & 0.15 & 0.43 \\
\hline $\begin{array}{c}\text { Gain in anterior disc } \\
\text { height (15) }\end{array}$ & 0.00 & 0.85 & $\begin{array}{c}\text { Gain in left foramen } \\
\text { height (15) }\end{array}$ & -0.7 & 0.004 \\
\hline $\begin{array}{c}\text { Gain in posterior disc } \\
\text { height (15) }\end{array}$ & 0.12 & 0.19 & $\begin{array}{c}\text { Gain in right foramen } \\
\text { height (15) }\end{array}$ & 0.25 & 0.35 \\
\hline
\end{tabular}

most common complications from LLIF are attributed to injury of the iliolumbar plexus, hematoma of the psoas, ureter injury, and intestinal loop injuries. ${ }^{6}$

This process not only ensures proper grafting, but also allows uniform distraction of the disc space, which restores disc height and facilitates reduction of the deformity through ligamentotaxis. ${ }^{7,13-15}$

The objective of interbody fusion and lateral access techniques is to preserve the load-bearing capacity of the spine, restore coronal and sagittal alignment, ${ }^{16-18}$ restore disc height, disc space, and foraminal dimensions, $6,7,19,20$ and use compression and stability to increase the probability of fusion. ${ }^{21-23}$

Remember that, from the biomechanical perspective, $80 \%$ of compression torsion, and shear forces are transmitted through the anterior spine. ${ }^{24-25}$ One of the advantages of LLIF in relation to posterolateral accesses (posterior lumbar interbody fusion (PLIF) and transforaminal lumbar interbody fusion (TLIF)) is the large area that the LLIF spacer has for bone growth. The spacer and the graft are positioned in front of the instantaneous rotation access and are exposed to compression instead of forces of traction, creating a favorable environment for stabilization and bone consolidation. ${ }^{26,27}$ Thus fusion rates following interbody fusion are considerably higher than those following posterolateral fusion, ${ }^{28-32}$ in that the rates of pseudarthrosis after posterolateral fusion hover around $20 \%$. ${ }^{33,34}$ The fusion rate of the series in the present study is similar to that found in other studies, ranging from 90 to $100 \%$. $^{35,36}$

Relief from neurogenic pain after LLIF corroborates the hypothesis that the technique is able to achieve the indirect decompression necessary to treat central and/or lateral stenosis (Figure 5), preventing the need for direct resection of the posterior elements and, with this, the associated morbidities. However, indirect decompression may be limited in cases of congenital stenosis and/or facet ankylosis. ${ }^{7}$ Its effect may also be reduced by the sinking of the implant. ${ }^{8,37}$

It was perceived that patients with high pelvic incidence have a better profile for the effect of interbody distraction. It was also observed that the degree and the stiffness of the adult spinal deformity can limit the effects of ligamentotaxis, which is critical for indirect neural compression by LLIF.

This study also showed that the influence of the gain in canal decompression in patients with high pelvic incidence varies in cases of patients with greater segmental lordosis and greater anterior disc height. Therefore, indirect neural decompression is not limited by the severity of the spinal stenosis and should be considered as an alternative to conventional direct neural decompression.

The effect of LLIF indirect neural decompression was greater in disc levels L2-L3 and L3-L4 than in the other levels. This can be explained by the limitations in approaching the disc and, mainly, the insertion of the cage without causing any damage to the terminal plate, which can lead to unsatisfactory positioning of the cage and even to the sinking of the cage. It is important to remember that, being patients with high pelvic incidence, those who have a high iliac crest may present a certain degree of technical difficulty in the access to level L4-L5.

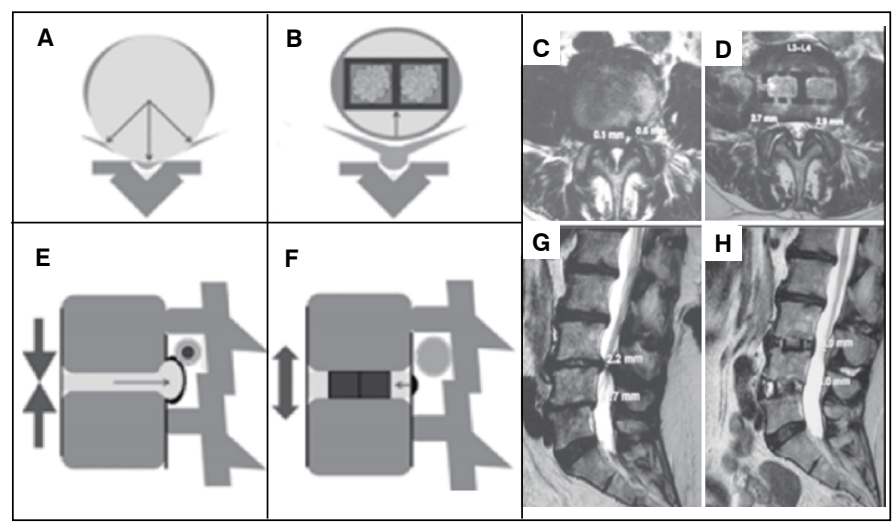

Figure 5. Concept and case of indirect decompression in sagittal and axial views. (A) and (C) - Axial view of the reduction of disc space with central and foraminal stenosis; (B) and (D) - Axial view of the interbody implant with restoration of the disc space and ligamentotaxis, causing indirect decompression; (E) and (G) - Sagittal view of the reduction of the disc space with central and foraminal stenosis; $(F)$ and $(H)$ - Sagittal view of the interbody implant with restoration of the disc space and ligamentotaxis, causing indirect decompression.

\section{CONCLUSIONS}

The effect of indirect neural decompression using the LLIF technique in patients with high pelvic incidence varies with the degree of segmental lumbar lordosis and anterior disc height.

Despite optimistic results, the need for more studies with greater numbers of patients, as well as prospective, randomized studies, is understood.

Nevertheless, this technique has the potential to control and correct adult spinal deformity misalignment, proving to be safe and effective to achieve thoracolumbar arthrodesis and promote decompression of the neural elements. However, in cases where there are persistent symptoms of neurogenic claudication or leg pain, posterior decompression should be performed.

All authors declare no potential conflict of interest related to this article. 
CONTRIBUTION OF THE AUTHORS: Each author made significant individual contributions to this manuscript. TGS contributed to the concept, the writing of the article, and the acquisition, analysis, and interpretation of the study data. RAA contributed to the design of the article and the critical review of its intellectual content. RRP contributed to the de-sign of the article and critical review of its intellectual content. LP contributed to the design of the article, the critical review of its in-tellectual content, and the approval of the final version of the manuscript to be published.

\section{REFERENCES}

1. Szpalski M, Gunzburg R, Mélot C, Aebi M. The aging of the population: a growing concern for spine care in the twenty-first century. Aging Spine. 2005:1-3. doi:10.1007/3-540$27376-X 1$

2. Weinstein JN, Tosteson TD, Lurie JD, Tosteson AN, Blood E, Hanscom B, et al. Surgical versus nonsurgical therapy for lumbar spinal stenosis. N Engl J Med. 2008:358(8):794-810. doi: 10.1056/NEJMoa0707136

3. Genevay S, Atlas SJ. Lumbar Spinal Stenosis. Best Pract Res Clin Rheumatol. 2010;24(2):253-65. doi: 10.1016/j.berh.2009.11.001

4. Shah M, Kolb B, Yilmaz E, Halalmeh DR, Moisi MD. Comparison of Lumbar Laminectomy Alone, Lumbar Laminectomy and Fusion, Stand-alone Anterior Lumbar Interbody Fusion, and Stand-alone Lateral Lumbar Interbody Fusion for Treatment of Lumbar Spinal Stenosis: A Review of the Literature. Cureus. 2019;11(9):e5691. doi:10.7759/cureus.5691

5. Paiva VC. História Natural da Estenose do Canal Lombar: Aspectos Clínicos e do Equilíbrio Sagital [Dissertação]. Campinas: Universidade Estadual de Campinas; 2018.

6. Ozgur BM, Aryan HE, Pimenta L, Taylor WR. Extreme Lateral Interbody Fusion (XLIF): a novel surgical technique for anterior lumbar interbody fusion. Spine J. 2006;6(4):435-43. doi: 10.1016/j.spinee.2005.08.012

7. Oliveira L Marchi L Coutinho E. Pimenta L. A Radiographic Assessment of the Ability of the Extreme Lateral Interbody Fusion Procedure to Indirectly Decompress the Neural Elements. Spine (Phila Pa 1976). 2010;35(26 Suppl): S331-7. doi: 10.1097/BRS.0b013e3182022db0

8. Marchi L, Abdala N, Oliveira L, Amaral R, Coutinho E, Pimenta L. Radiographic and clinica evaluation of cage subsidence after stand-alone lateral interbody fusion. J Neurosurg Spine. 2013;19(1):110-8. doi: 10.3171/2013.4.SPINE12319

9. Grant JP, Oxland TR, Dvorak MF. Mapping the structural properties of the lumbosacra vertebral endplates. Spine (Phila Pa 1976). 2001;26(8):889-96. doi: 10.1097/00007632 200104150-00012

10. Uribe JS, Deukmedjian AR, Mummaneni PV, Fu KMG, Mundis GM, Okonkwo DO, et al. Complications in adult spinal deformity surgery: An analysis of minimally invasive, hybrid, and open surgical techniques. Neurosurg Focus. 2014;36(5):E15. doi:10.3171/2014.3.FOCUS13534

11. Smith C, Lamba N, Ou Z, Vo Q-A, Araujo-Lama L, Lim S, et al. The prevalence of complications associated with lumbar and thoracic spinal deformity surgery in the elderly population: a meta-analysis. J Spine Surg. 2019;5(2):223-35. doi: 10.21037/ jss.2019.03.06

12. Daubs MD, Lenke LG, Cheh G, Stobbs G, Bridwell KH. Adult Spinal Deformity Surgery: complications and outcomes in patients over age 60. Spine (Phila Pa 1976). 2007;32(20):223844. doi: 10.1097/BRS.0b013e31814cf24a

13. Pimenta L, Tohmeh A, Jones D, Amaral R, Marchi L, Oliveira L, et al. Rational decision making in a wide scenario of different minimally invasive lumbar interbody fusion approaches and devices. J Spine Surg. 2018;4(1):142-55. doi: 10.21037/ jss.2018.03.09

14. Youssef JA, McAfee PC, Patty CA, Raley E, DeBauche S, Shucosky E, et al. Minimally Invasive Surgery: Lateral Approach Interbody Fusion. Spine (Phila Pa 1976). 2010;35(26 Suppl):S302-11. doi: 10.1097/BRS.0b013e3182023438

15. Mobbs RJ, Phan K Malham G, Seex K Rao PJ. Lumbar interbody fusion: techniques, indications and comparison of interbody fusion options including PLIF, TLIF, MI-TLIF, OLIF/ATP, LLIF and ALIF. J Spine Surg. 2015;1(1):2-18. doi: 10.3978/j.issn.2414-469X.2015.10.05

16. Nakashima H, Kanemura T, Satake $K$, Ishikawa $Y$, Ouchida J, Segi N, et al. Factors af fecting postoperative sagittal alignment after lateral lumbar interbody fusion in adult spinal deformity: Posterior osteotomy, anterior longitudinal ligament rupture, and endplate injury. Asian Spine J. 2019;13(5):738-45. doi: 10.31616/asj.2018.0275

17. Dakwar E, Cardona RF, Smith DA, Uribe JS. Early outcomes and safety of the minimally invasive, lateral retroperitoneal transpsoas approach for adult degenerative scoliosis. Neurosurg Focus. 2010;28(3):1-7. doi: 10.3171/2010.1.FOCUS09282
18. Ahlquist S, Park HY, Gatto J, Shamie AN, Park DY. Does approach matter? A comparative radiographic analysis of spinopelvic parameters in single-level lumbar fusion. Spine J. 2018;18(11):1999-2008. doi: 10.1016/j.spinee.2018.03.014

19. Kelleher MO, Timlin M, Persaud O, Rampersaud YR. Success and failure of minimally invasive decompression for focal lumbar spinal stenosis in patients with and without deformity. Spine (Phila Pa 1976). 2010;35(19):E981-7. doi: 10.1097/BRS.0b013e3181c46fb4

20. Kosztowski T, Goodwin CR, Petteys R, Sciubba D. Assessing the Need for Decompression for Adult Lumbar Scoliosis. In: Klineberg EO. Adult Lumbar Scoliosis. Switzerland: Springer; 2017; 123-39.

21. Pelletier $\mathrm{MH}$, Cordaro N, Punjabi VM, Waites $M$, Lau A, Walsh WR. PEEK Versus Ti Interbody Fusion Devices. Clin Spine Surg. 2016;29(4):E208-14. doi: 10.1097/ BSD.0b013e31826851a4

22. Keorochana G, Setrkraising $K$, Woratanarat $P$, Arirachakaran A, Kongtharvonskul J. Clinical outcomes after minimally invasive transforaminal lumbar interbody fusion and lateral lumbar interbody fusion for treatment of degenerative lumbar disease: a systematic review and meta-analysis. Neurosurg Rev. 2018:41(3):755-70. doi: 10.1007/s10143-016-0806-8

23. Seaman S, Kerezoudis P, Bydon M, Torner JC, Hitchon PW. Titanium vs. polyetheretherketone (PEEK) interbody fusion: Meta-analysis and review of the literature. J Clin Neurosci. 2017;44:23-9. doi: 10.1016/j.jocn.2017.06.062

24. Harms J. Screw-Threaded Rod System in Spinal Fusion Surgery. In: Dorman TA. Spine: State of the Art Reviews. Philadelphia: Hanley \& Belfus; 1992. p. 541-75

25. Yang SW, Langrana NA, Lee CK. Biomechanics of lumbosacral spinal fusion in combined compression-torsion loads. Spine (Phila Pa 1976). 1986;11(9):937-41. doi: 10.1097/00007632-198611000-00014

26. Voor MJ, Mehta S, Wang M, Zhang YM, Mahan J, Johnson JR. Biomechanical evaluation of posterior and anterior lumbar interbody fusion techniques. J Spinal Disord. 1998;11(4):328-34

27. Evans JH. Biomechanics of lumbar fusion. Clin Orthop Relat Res. 1985;(193):38-46.

28. Ma GW. Posterior lumbar interbody fusion with specialized instruments. Clin Orthop Relat Res. 1985:(193):57-63.

29. Steffee AD, Sitkowski DJ. Posterior lumbar interbody fusion and plates. Clin Orthop Relat Res. 1988;227:99-102.

30. Fujimaki A, Crock HV, Bedbrook GM. The results of 150 anterior lumbar interbody fusion operations performed by two surgeons in Australia. Clin Orthop Relat Res. 1982;(165):164-7.

31. Blumenthal SL, Baker J, Dossett A, Selby DK. The role of anterior lumbar fusion for internal disc disruption. Spine (Phila Pa 1976). 1988:13(5):566-9. doi: 10.1097/00007632198805000-00023

32. Benton BF, Calandruccio RA. Surgical technic of anterior lumbar fusion. Am Surg 1966:32(2):134-6.

33. Parker LM, Murrell SE, Boden SD, Horton WC. The outcome of posterolateral fusion in highly selected patients with discogenic low back pain. Spine (Phila PA 1976). 1996;21(16):190916. doi: 10.1097/00007632-199706150-00025

34. Turner JA, Ersek M, Herron L, Haselkorn J, Kent D, Ciol MA, et al. Patient outcomes after lumbar spinal fusions. JAMA. 1992;268(7):907-11.

35. Rodgers WB, Cox C, Gerber E. Experience and early results with a minimally invasive technique for anterior column support through eXtreme lateral interbody fusion (XLIF®). US Musculoskelet Dis. 2007:2(1):28-32.

36. Rodgers WB, Gerber EJ, Patterson JR. Fusion after minimally disruptive anterior lumbar interbody fusion: Analysis of extreme lateral interbody fusion by computed tomography. SAS J. 2010;4(2):63-6. doi: 10.1016/j.esas.2010.03.001. eCollection 2010

37. Lang G, Perrech M, Navarro-Ramirez R, Hussain I, Pennicooke B, Maryam F, et al. Potential and Limitations of Neural Decompression in Extreme Lateral Interbody Fusion-A Systematic Review. World Neurosurg. 2017;101:99-113. doi: 10.1016/j. wneu.2017.01.080 